\title{
VOCES DE SEDA. LAS PINTURAS CLANDESTINAS DE AGUSTÍN IBARROLA (1962-1965)
}

\author{
Noemi de Haro García \\ Universidad Autónoma de Madrid \\ noemi.deharo@uam.es
}

\begin{abstract}
Durante su encarcelamiento en el Penal de Burgos entre 1962 y 1965 el artista Agustín Ibarrola pintó obras críticas de forma clandestina. Éstas fueron expuestas en España pero, sobre todo, en varios países europeos apoyando las protestas contra la dictadura. Este artículo se basa en documentación inédita para estudiar dichas exposiciones. Se dedica especial atención a la red de solidaridad y apoyo que hizo posible estas exposiciones así como a la reacción ante ellas por parte de los sistemas de control y represión del franquismo.

Palabras clave: Agustín Ibarrola; Penal de Burgos; Presos Políticos; Movimientos sociales; Amnistía; Antifranquismo; Arte y Política.
\end{abstract}

\section{SILK VOICES. AGUSTÍN IBARROLA'S CLANDESTINE PAINTINGS (1962-1965)}

During his imprisonment in the Prison of Burgos between 1962 and 1965 the artist Agustín Ibarrola clandestinely painted critical artworks. These paintings were exhibited in Spain, but notably in several European countries where they were part of protest movements against the dictatorship. This paper gathers unpublished information in order to study these exhibitions. Special attention is devoted to the solidarity network that supported and made these exhibitions possible, as well as to the reactions they provoked in the control and repression systems of the Franco regime.

Keywords: Agustín Ibarrola; Prison of Burgos; Political Prisoners; Social Movements; Amnesty; Anti-Franco regime; Art \& Politics.

Noticias de París señalan que en una galería de arte de dicha Capital [sic], sita en el Barrio Latino [sic], se ha inaugurado una exposición de obras del Pintor [sic] Agustín IBARROLA [sic], realizadas en la prisión de Burgos donde se encuentra detenido. (...)

La sala, más bien pequeña, aparecía abarrotada de público, compuesto de los mismos de siempre (...) y de otro público "elegante" asíduo [sic] a estas manifestaciones de arte que tienen lugar a diario en París. (...)

Lo más chocante eran las propias pinturas expuestas. Se trataba de lienzos muy grandes, más bien estrechos, pero muy largos, algunos hasta de tres metros, pintados sobre lienzos de seda, a la "gouache", en tonos sepias y ocres, representando escenas del interior de la cárcel: grupos alineados de presos ante las celdas, preso escuálido con un fondo de barrotes... destacando, de entre todos, uno, también de grandes dimensiones, pero éste al óleo sobre lienzo de aspillera [sic], representado el patio de la cárcel de Burgos, blanco de nieve, sobre la que sólo estaban señaladas las huellas dejadas 
por el paseo cotidiano y circular de los detenidos. Así, la pregunta que todos se hacían era cómo había sido posible sacar de la cárcel esos cuadros sin el consentimiento de las autoridades ${ }^{1}$.

El informante del Alto Estado Mayor que remitía esta breve crónica a la Oficina de Enlace no podía ocultar su sorpresa ante lo que había visto. Es cierto que hacía notar la pequeñez de la sala, también señalaba que los visitantes eran "los mismos de siempre" junto con quienes en París iban a todas las exposiciones sin importar de qué se tratase. Con ello quizá estaba tratando de dar a entender que no se trataba de un acontecimiento que pudiera tener una repercusión importante en Francia. Pero la muestra era impactante. Y esto sólo podía inquietar al régimen. ¿Cómo habían salido del Penal de Burgos unas pinturas semejantes?, es más ¿cómo habían podido ser pintadas siquiera? ${ }^{2}$

Los diversos agentes de información, control y represión del régimen estuvieron muy atentos a las exposiciones de las obras pintadas en la cárcel por Agustín Ibarrola. Por un lado, las obras denunciaban la falta de libertades, la injusticia y la violencia que sustentaban una dictadura se presentaba como moderna, pacífica y humana. Por otro, la mera existencia de las pinturas y de las exposiciones eran la evidencia de que el régimen franquista no era inexpugnable (era posible burlarlo) y de que existía una red nacional e internacional de apoyo al antifranquismo. En este caso concreto, la parte más importante de dicha red de apoyo la constituía el movimiento en defensa de la amnistía a los presos políticos, relacionado con el apoyo a la defensa de los derechos humanos y (aunque esta relación tuviera grados distintos en cada caso) con el Partido Comunista de España (PCE) y sus homólogos en otros países.

El 13 de junio de 1962, por virtud de la Diligencia no 2939, Francisco Roselló Colombás, inspector jefe de la Brigada Regional de Investigación Social de la Jefatura Superior de Policía de Bilbao, dispuso que los funcionarios del Grupo Primero de dicha Brigada llevaran a cabo las actuaciones necesarias para detener a los "agitadores del Partido Comunista" que estaban desarrollando "gran actividad subversiva, aprovechándose de las propicias circunstancias producidas con motivo de los recientes conflictos laborales que han afectado a la mayor parte de la industria vizcaína". Dichos "agitadores" estaban sirviendo de informadores a la conocida (y comunista) Radio España Independiente (REI) así como a otras agencias de noticias extranjeras. Se trataba de tres miembros del PCE: Ramón Ormazábal Tife, miembro del Comité Central, y Gregorio Rodríguez Gordon que habían llegado desde Francia, así como de Agustín Ibarrola Goicoechea. Ninguno de los tres debía de estar al tanto de que les vigilaban cuando se reunieron en la playa de Ereaga. En la documentación se indica que Ibarrola reconoció a uno de los funcionarios que les seguían y huyó. Esto habría motivado la detención inmediata de Ormazábal y Rodríguez Gordon: la policía decía haber temido que huyeran de haber esperado a otra ocasión. Apresaron a Ibarrola poco después, cerca de Bilbao ${ }^{3}$. En la entrevista que Javier Angulo Barturen hizo a Ibarrola en 1978 éste confirmaba que, efectivamente, había reconocido a un policía porque le había visto en sus expo-

${ }^{1}$ Exposición de pinturas de IBARROLA en París. Documento remitido por el Alto Estado Mayor al la Oficina de Enlace, 30-VI-1965, Archivo General de la Administración, Alcalá de Henares (AGA), (03) 107, Caja 42/8801, dossier de Agustín Ibarrola Goicoechea.

${ }^{2}$ La autora desea dar las gracias a Agustín Ibarrola y Mariluz Bellido por su trabajo, su testimonio y su colaboración. Sin ellos y sin las redes de personas implicadas nada de lo que aquí mostramos existiría. También desea agradecer la inestimable ayuda de José Ibarrola, José Ángel Etxániz, Iris de Leeuw, Leopoldo Maler, Manuel Calvo, Gérard y Georgette Gosselin, José Cristóbal Cárdenas y Emilio Quintana, Jacopo Galimberti, Hannah Williamson y Ruth Milner de las Manchester City Galleries. Este trabajo se ha realizado gracias a un contrato JCI-2010-07552, una estancia de movilidad "José Castillejo" (CAS12/00397) y una beca en la Real Academia de España en Roma. Está vinculado al proyecto de investigación HAR2012-32609. 2015/EEUU/04 y HAR2015-67059-P (MINECO/FEDER).

${ }^{3}$ Consejo de Guerra contra Ramón Ormazábal Tife y once detenidos más. Archivo Histórico de Defensa, Madrid (AHD), Fondo Madrid, Sumario 878, Legajo 3154. 
siciones. Sin embargo, según el artista, fueron los propios policías quienes optaron por ir tras sus compañeros aun cuando él mismo había tratado de distraerles sin éxito 4 .

Los tres detenidos fueron presentados por los funcionarios a las 10:40 horas del 14 de junio de $1962^{5}$. A partir de aquí se sucederían los interrogatorios y las declaraciones, que darían lugar a una larga cadena de detenciones. María Dapena, Gonzalo José Villate, Vidal de Nicolás, Antonio Giménez Pericás, Andrés Pérez ${ }^{6}$, José María Ibarrola y Enrique Múgica, además de Ramón Ormazábal, Gregorio Rodríguez y Agustín Ibarrola serían juzgados y condenados en el Consejo de Guerra celebrado el 21 de septiembre de 1962. En concreto Agustín Ibarrola fue acusado de estar en contacto con los dirigentes del PCE encartados en el procedimiento, de haber recibido y realizado la misión de informar a las emisoras de radio extranjeras, de ser el enlace entre organismos franceses e individualidades del País Vasco y de que "al amparo de su profesión artística y encubierto por ésta (...) [había puesto toda su actividad] al servicio del Partido Comunista"7.

En el acta-declaración de Ibarrola fechada el 16 de junio se señalaba su relación con el mundo artístico español y parisino, con los miembros del Equipo 57 y con quien le había propuesto entrar en el PCE: el pintor José Ortega, conocido comunista que había estado encarcelado y sobre el que pesaba una orden de busca y captura en España. Entre otras cosas, y aparte de explicar cómo y adónde enviaba los informes para REI, en dicha acta-declaración se indicaba que María Dapena y su marido habían ayudado a Ibarrola con estos informes ${ }^{8}$. En la documentación policial consultada no hay datos acerca de las condiciones bajo las que se realizaban los interrogatorios y se obtenían las declaraciones. En el resumen del Consejo de Guerra aparecido en el libro Ramón Ormazábal y sus compañeros se indica que durante el juicio Ibarrola denunció que los informes policiales habían sido obtenidos con torturas y que, por decir esto en el juicio, Ibarrola había sido sacado de la sala9. Esto no aparece en la documentación de archivo del Consejo de Guerra. Nada se dice en la documentación oficial acerca de la violencia de las detenciones, del trato en las dependencias policiales, o de otras formas de tortura ${ }^{10}$. Precisamente por ello resultan tan inquietantes las pocas líneas en las que se comunica el traslado al hospital de Gonzalo José Villate a las pocas horas de su detención por intento de suicidio ${ }^{11}$. María Dapena explica que su marido había tratado de evitar así la segunda paliza policial ${ }^{12}$.

Agustín Ibarrola fue condenado a nueve años de cárcel. En la Prisión Central de Burgos encontró una gran cantidad de presos políticos y una vida muy organizada ${ }^{13}$. Ibarrola había comen-

${ }^{4}$ Angulo, 1978: 144

${ }^{5}$ Consejo de Guerra contra Ramón Ormazábal Tife y once detenidos más. AHD, Fondo Madrid, Sumario 878, Legajo 3154.

${ }^{6}$ A estas cinco personas las presentaron detenidas al mismo tiempo. Consejo de Guerra contra Ramón Ormazábal Tife y once detenidos más. AHD, Fondo Madrid, Sumario 878, Legajo 3154.

7 Consejo de Guerra contra Ramón Ormazábal Tife y once detenidos más. AHD, Fondo Madrid, Sumario 878, Legajo 3154.

${ }^{8}$ Consejo de Guerra contra Ramón Ormazábal Tife y once detenidos más. AHD, Fondo Madrid, Sumario 878, Legajo 3154.

9 VV.AA., Ramón Ormazábal y sus compañeros, París, Comité National de Défense des Victimes du Franquisme, s/f [1962] : 40. Fragmentos del interrogatorio fueron ampliamente traducidos, reproducidos y difundidos. Se encuentran, por ejemplo, en el libro España hoy (publicado por Ruedo Ibérico en 1963), en la revista La Nouvelle Critique francesa (IX/X-1963), o en la italiana Rinascita (6-IV-1963: 17-20).

${ }^{10}$ María Dapena narra su detención en la madrugada del 15 de junio de 1962 y su experiencia en los calabozos policiales en su libro iSr. Juez! (soy presa de Franco...) (Dapena, 1978: 7-10).

${ }^{11}$ Consejo de Guerra contra Ramón Ormazábal Tife y once detenidos más. AHD, Fondo Madrid, Sumario 878, Legajo 3154.

${ }_{12}$ Dapena, 1978: 18.

13 Angulo, 1978: 147. 
zado a pintar a lápiz sobre hojas holandesas ya en la cárcel de Carabanchel donde estuvo antes del juicio. En Burgos le dieron permiso oficial para pintar pero, en paralelo a su actividad pictórica permitida y controlada, hizo obras clandestinas sobre lienzos de seda utilizando las pinturas para pintar sobre tela que le proporcionaba su mujer Mariluz Bellido. Además de esta técnica, Ibarrola empleó tinta china sobre un papel muy delgado. Los tamaños de estas pinturas clandestinas eran diversos, algunas eran pequeñas pero otras no. A veces, en los casos de las obras de mayor tamaño, trabajaba con la seda plegada o dividida en piezas que se ensamblaban posteriormente. Los temas principales de estas obras eran las duras condiciones de vida en la cárcel, las detenciones, los juicios y las torturas. También había retratos y composiciones que mostraban la fuerza y la unión de los presos políticos, su resistencia a las torturas, su potencial revolucionario, el vigor del antifranquismo y la necesidad de levantarse contra el opresor.

Para pintar Ibarrola contó con la ayuda de red del PCE en la cárcel. Cuando el artista indicaba que quería trabajar se le citaba a una hora en un lugar y allí le suministraban los materiales y vigilaban mientras pintaba. En caso de que hubiera peligro sus compañeros lo retiraban y ocultaban todo $^{14}$. Esta misma red, en conexión con otras, era la encargada de esconder las obras terminadas, de hacerlas salir de la cárcel y de facilitar su circulación. Ni el artista, ni Mariluz Bellido saben cómo pudo hacerse todo esto ${ }^{15}$. José Ibarrola ha apuntado que la labor de Gervasio Puerta fue fundamental para que las pinturas de su padre salieran del Penal de Burgos ${ }^{16}$. Si bien no menciona las pinturas en sus memorias, este militante comunista sí habla de su responsabilidad en el control de la propaganda clandestina, la difusión de noticias y la ocultación de documentos y escritos en la cárcel, así como en la transmisión de mensajes al exterior. Éstos salían en recipientes de doble fondo, asas de bolsas, cigarrillos y cajetillas de tabaco, postales, libros, botes de cacao, etc. ${ }^{17}$. Seguramente los útiles empleados para pintar por Agustín Ibarrola pasaron por uno o por varios de los escondites preparados y custodiados por Puerta y otros camaradas. Quizá las pinturas terminadas fueron escondidas en algún paquete, salieron enrolladas en las asas de alguna bolsa, en un recipiente con doble fondo, o encuadernadas en algún libro... Que ignoremos esto indica no sólo el tiempo transcurrido y la escasez de testimonios, sino también la eficacia del sistema empleado para burlar el control carcelario.

Las exposiciones de las obras de Ibarrola se realizaron en el marco de una red antifranquista que se extendía dentro y fuera de España con el apoyo de organizaciones, grupos e individuos que enmarcaban sus demandas en la defensa de los derechos humanos, de la libertad de expresión y de la amnistía para los presos políticos. Esto contribuía a que sus demandas alcanzaran sus objetivos con más posibilidades de éxito en una época en la que la situación política, social y económica ya no era la de los años cuarenta y era necesario elaborar un discurso que, sin sofocar las resonancias de la lucha antifascista, favoreciera otras relacionadas con preocupaciones que se consideraban más cercanas y acuciantes. La campaña en relación con el juicio de Ramón Ormazábal y sus compañeros y la del caso Julián Grimau coincidieron en el tiempo y contribuyeron a despertar muchas conciencias acerca de la situación en España. Marcos Ana se refería a la detención y "suicidio" de Grimau en su prólogo al libro Ramón Ormazábal y sus compañeros donde había reproducciones de obras de José Ortega, Agustín Ibarrola y María Dapena ${ }^{18}$ (fig. 1).

\footnotetext{
${ }^{14}$ Angulo, 1978: 148-149.

15 Testimonios de Agustín Ibarrola y Mariluz Bellido en conversación con José Ibarrola, José Ángel Etxániz y la autora, Kortezubi (Vizcaya), 12-III-2011.

${ }^{16}$ Testimonio de José Ibarrola en conversación con Agustín Ibarrola, Mariluz Bellido, José Ángel Etxániz y la autora, Kortezubi (Vizcaya), 12-III-2011.

${ }_{17}^{17}$ Puerta, 2011: 102-117.

${ }^{18}$ VV.AA., Ramón Ormazábal y sus compañeros, París, Comité National de Défense des Victimes du Franquisme, $\mathrm{s} / \mathrm{f}[1962]$.
} 


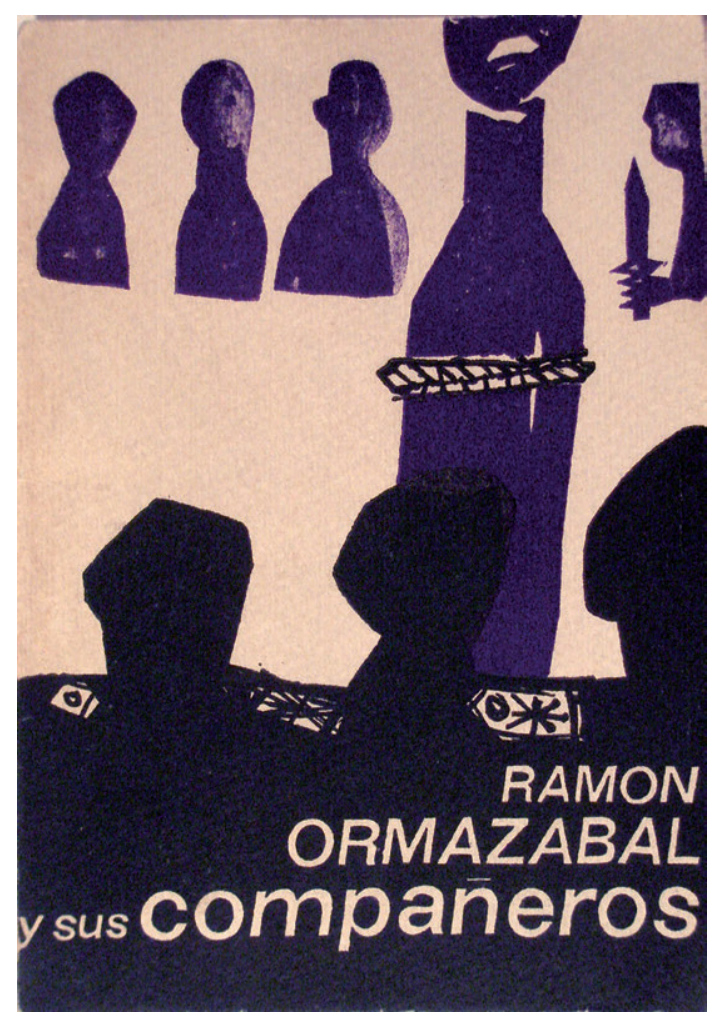

Fig. 1. Obra de José Ortega reproducida en la cubierta del libro Ramón Ormazábal y sus compañeros (París, 1962).

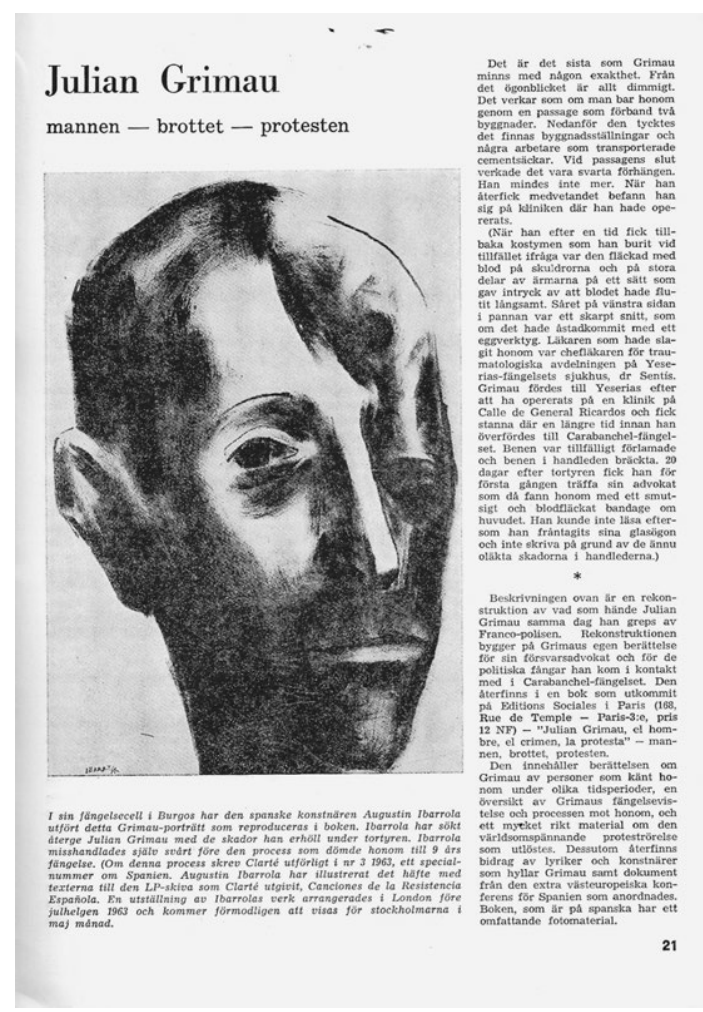

Fig. 2. Retrato de Julián Grimau por Agustín Ibarrola reproducido en la revista Clarté en 1965 (documento publicado en el trabajo de J.C. Cárdenas

y E. Quintana Ferlosio. 50 años de "Canciones de la resistencia española” - Clarté, en http://www.chichosanchezferlosio.es).

Según ha contado Mariluz Bellido, Ibarrola pintó en la cárcel el aspecto del rostro de Grimau tras las torturas policiales siguiendo las indicaciones de quienes le habían conocido puesto que nunca le había visto ${ }^{19}$. Esta obra sería reproducida, por ejemplo, en el libro de homenaje publicado tras su asesinato Julián Grimau. El Hombre. El crimen. La protesta ${ }^{20}$, o más tarde en el número de la revista socialista sueca Clarté de 1964 donde se traducía parte del citado libro de homenaje ${ }^{21}$ (fig. 2). En septiembre de 1963 Vicente Aguilera Cerni dedicaba a Ibarrola y Giménez Pericás su intervención en el XIII Convengo Internazionale Artisti, Critici e Studiosi d'Arte celebrado en Rí$\operatorname{mini}^{22}$. La situación de los encarcelados en Burgos, especialmente la de los pintores y críticos caló en los círculos artísticos. No en vano que un intelectual fuera encarcelado por motivos de opinión

\footnotetext{
19 Angulo, 1978: 152, 168.

20 VV.AA., Julián Grimau. El hombre. El crimen. La protesta, París, Éditions Sociales, 1963.

21 “Julian Grimau. Mannen - Brottet - Protesten”, Clarté, 3, 1964: 21. En el apartado dedicado a Ibarrola en la sección "Estampa Popular" de la web donde se publica el trabajo de Cárdenas, Quintana, s/f.

${ }^{22}$ Barreiro, 2009: 310.
} 
iba en contra de la idea de la necesidad de libertad para los artistas propugnada en el mundo artístico occidental.

El primer lugar donde se pudo ver un conjunto importante de las obras pintadas por Agustín Ibarrola en la cárcel fue en Londres gracias al apoyo de Appeal for Amnesty in Spain (AAS). Esta organización había iniciado sus actividades en 1959 y siempre se presentó al margen de toda ideología política ${ }^{23}$. Así estuvo presente, por ejemplo, en encuentros internacionales como la West European Conference for an Amnesty for Spanish Political Prisoners and Exiles ${ }^{24}$ que también se presentaba ajena a todo interés político ${ }^{25}$. Como ya se ha indicado, esto suponía cambiar el marco interpretativo que daba sentido a esta acción colectiva ${ }^{26}$. Las imágenes en general, y las obras de arte en particular, habían formado parte de las actividades de AAS desde el principio y desempeñaron un papel importante en la configuración de dicho marco interpretativo ${ }^{27}$. Desde sus inicios la organización se esforzó por trasladar a quienes la apoyaban datos sobre los presos políticos españoles y también sus testimonios. Éstos aparecían, por ejemplo, en las páginas de sus boletines informativos donde se reproducían cartas, poemas, entrevistas o fotografías de los presos y sus familiares. Las obras pintadas por Agustín Ibarrola en la cárcel combinaban características de todos esos materiales puesto que eran obras artísticas, testimoniales, icónicas, indiciales y clandestinas.

La muestra de Ibarrola en Londres, titulada from Burgos jail, tuvo lugar en la St. George's Gallery del 9 al 15 de diciembre de 1963. El crítico de arte Sir Herbert Read (sponsor de AAS) dio la conferencia inaugural. Esta exposición suponía un paso más en lo que, desde el verano de 1962, los servicios de control y vigilancia en España consideraban una campaña internacional específica de apoyo a los presos juzgados junto a Ormazábal ${ }^{28}$. Al tiempo que from Burgos jail se podía ver la exposición Goya and his times en la cercana Royal Academy. REI contaba que no sólo se habían dejado folletos de la muestra de Ibarrola dentro de la Royal Academy, sino que seis diputados laboristas los habían repartido a las puertas de la exposición de Goya señalando que, si bien las obras de este último se encontraban en la Royal Academy, "el espíritu de Goya" estaba en la galería cercana $^{29}$. Del mismo modo -se decía en los folletos- que el gobierno español era el responsable de que se pudieran ver las obras de Goya en la Royal Academy, también lo era de la exposición de Ibarrola puesto que le había encarcelado por apoyar las huelgas de Asturias ${ }^{30}$ (fig. 3). Copias del folleto acompañaban a las notas que fueron enviadas a la Oficina de Enlace, al Alto Estado Mayor y a la Dirección General de Seguridad. En ellas se explicaba que la exposición era una "maniobra propagandística (...) puramente política" que aprovechaba la exposición de Goya para atraer la atención ${ }^{31}$.

${ }^{23}$ Con todo, para muchos, esta organización estaba controlada por el Communist Party of Great Britain (CPG). Buchanan, 2002: 580.

${ }^{24}$ El nombre del encuentro y la organización aparece en distintos idiomas: West European Conference for an Amnesty for Spanish Political Prisoners and Exiles, Conférence d'Europe Occidentale pour l'Amnistie aux emprisonnés et exilés politiques espagnols, Conferencia de Europa Occidental en Pro de la Amnistía para los Presos y Exiliados Políticos de España, etc.

25 "Al pleno de la Conferencia pro amnistía, que se reunirá en París en el mes de marzo", [1961], s/p. Archivo de la Embajada de España ante la Santa Sede, Roma. Legajo 229.

${ }^{26}$ De Haro, 2014: 107-120.

27 Sobre el papel de las imágenes en AAS véase De Haro, 2014: 107-120.

${ }^{28}$ En la Sala de Consejos de la Auditoría Militar. Nota Informativa Confidencial de la Oficina de Información Diplomática, Madrid, 22-IX-1962, AGA, (03) 107, Caja 42/8801, dossier de Agustín Ibarrola Goicoechea.

${ }^{29}$ Carta de Londres. Emisión de REI de 9-I-1964 transcrita y archivada por la Oficina de Enlace. AGA, (03) 107, Caja 42/8801, dossier de Agustín Ibarrola Goicoechea.

${ }^{30}$ Drawings from Burgos Jail by the imprisoned Spanish painter Agustín Ibarrola (folleto de la exposición), Londres, St George's Gallery, XII-1963. AGA, (03) 107, Caja 42/8801, dossier de Agustín Ibarrola Goicoechea.

${ }^{31}$ Londres. Nota para la Oficina de Enlace, Madrid, 20-XII-1963. AGA, (03) 107, Caja 42/8801, dossier de Agustín Ibarrola Goicoechea. 

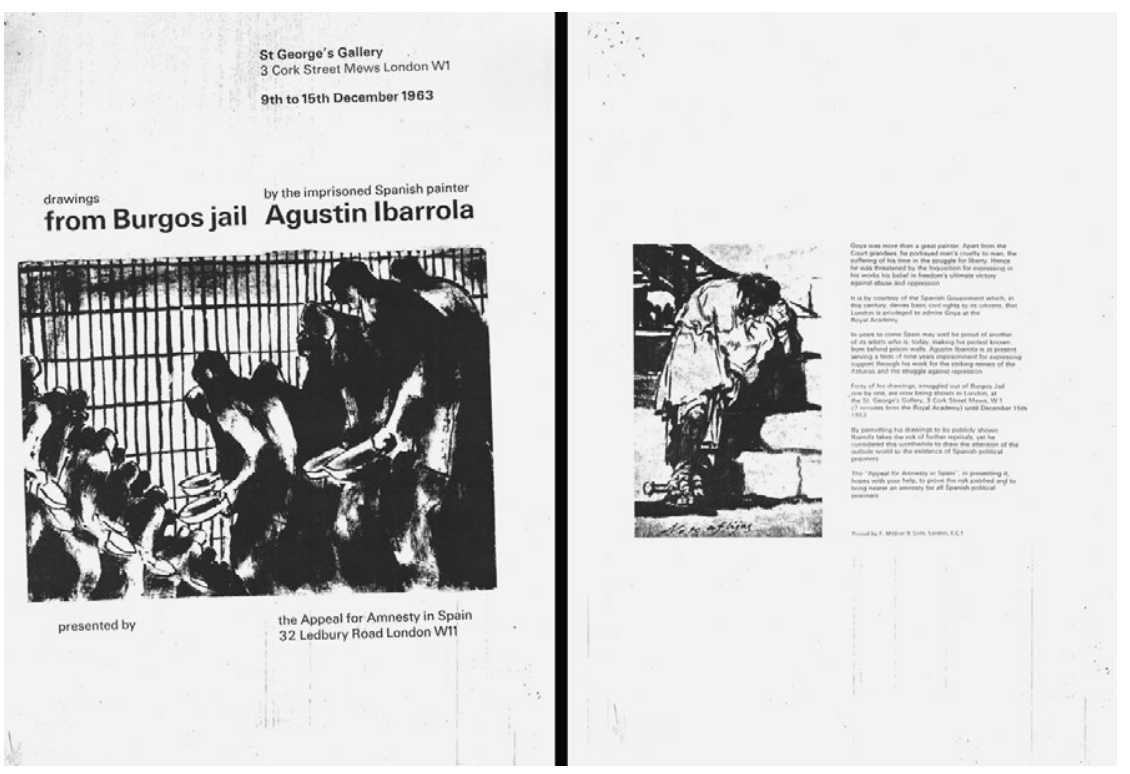

Fig. 3. Anverso y reverso del folleto anunciador de la exposición from Burgos jail (St. George's Gallery, Londres, 1963).

La St. George's Gallery, abierta por Robert Erskine a mediados de los años cincuenta, fue pionera en su impulso a la creación contemporánea en el campo de la estampa británica tras la Segunda Guerra Mundial ${ }^{32}$. Si bien las obras que exponía en Londres no eran estampas, Ibarrola colaboraba y exponía ya entonces con los colectivos de Estampa Popular ${ }^{33}$. Y desde luego su trabajo encajaba con la línea de una galería que, por ejemplo, también exponía a Picasso. En la exposición había tres obras de mayor tamaño: los paneles titulados Yesterday, Today y Tomorrow que componían una especie de tríptico sobre la España del pasado, del presente y del futuro. Las pinturas más pequeñas denunciaban la vulneración de los derechos humanos por el sistema represivo franquista. Junto con estos temas había retratos y escenas en las que se mostraba la unión y la solidaridad entre los presos. From Burgos jail circuló por varias ciudades inglesas: se pudo ver del 7 al 21 de enero de 1964 en el City Art Gallery Annexe en Manchester ${ }^{34}$ y luego también en Sheffield y Reading. A ambas exposiciones se refería Eileen Turner en la carta en la que anunciaba a sus simpatizantes que AAS había publicado from Burgos jail ${ }^{35}$ (fig. 4). Este librito, que se vendía por cinco chelines, recogía obras realizadas en la cárcel de Burgos: 8 poemas escritos por Marcos Ana, 5 por Vidal de Nicolás, y 15 obras de Ibarrola ${ }^{36}$.

${ }^{32}$ Wye, 2006: 47. Véase, por ejemplo, cómo era presentada la galería por Leslie Adrian, "Pictures for the Poor", The Spectator, 24-VII-1959, 16.

${ }^{33}$ La actividad expositiva de Ibarrola, Dapena y los demás miembros de Estampa Popular de Vizcaya se había iniciado en 1962. Mientras estuvieron encarcelados sus obras fueron incluidas en varias exposiciones colectivas de Estampa Popular. Sobre las actividades de Estampa Popular véase De Haro, 2010a.

${ }^{34}$ Drawings from Burgos jail by the imprisoned Spanish painter Agustin Ibarrola (folleto de la exposición) Manchester, Art Gallery Annexe, I-1964.

${ }^{35}$ Carta enviada por Eileen Turner como secretaria honorífica de Appeal for Amnesty in Spain, Londres, IV-1964. Archivo personal de Manuel Irujo depositado en Eusko Ikaskuntza. Disponible en la web de la Fundación Euskomedia http://www.euskomedia.org/PDFFondo/irujo/2547.pdf [Consulta: 14/09/2014]

${ }^{36}$ Agustín Ibarrola, Marcos Ana, Vidal de Nicolás, from Burgos jail, Londres, Appeal for Amnesty in Spain, 1964. Papers of Richard Albert Etheridge, Modern Records Centre, University of Warwick (MRC, UW), MSS.202/5/40. 

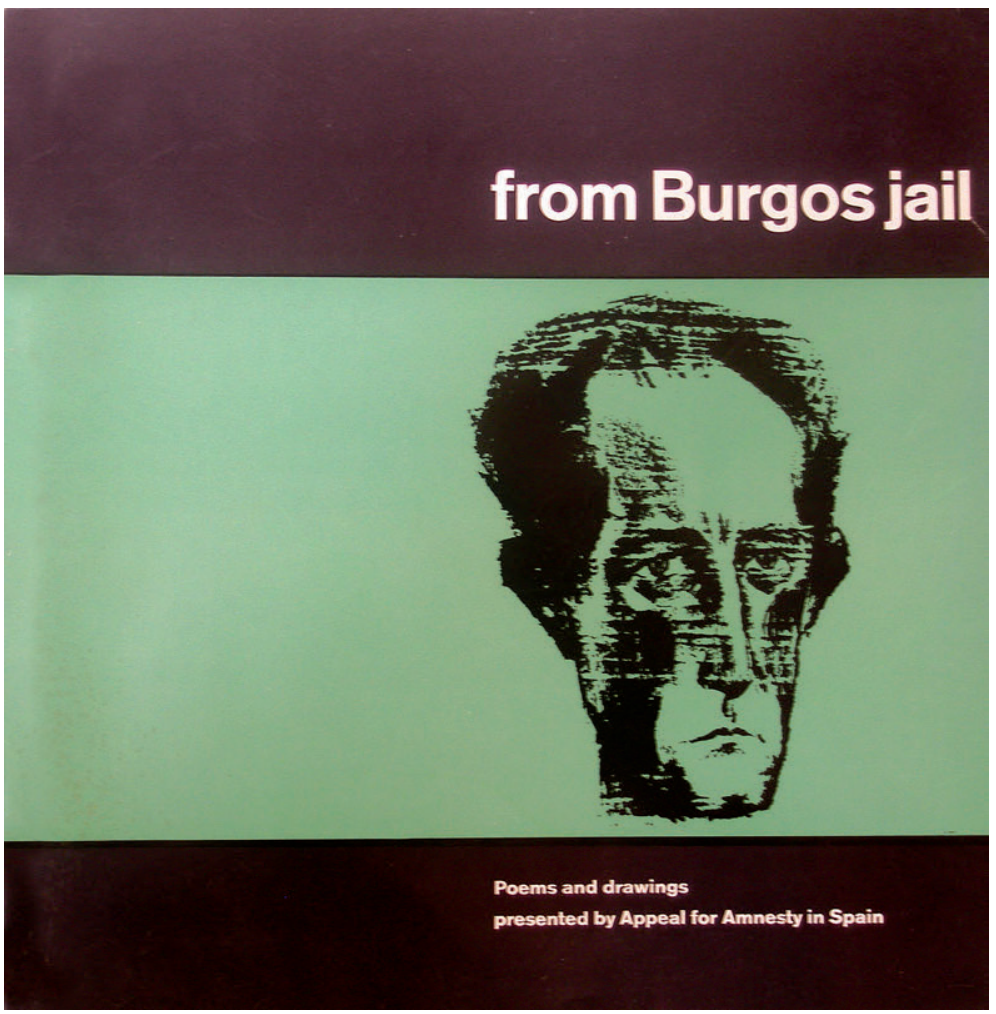

Fig. 4. Retrato de Vidal de Nicolás por Agustín Ibarrola, reproducido en la cubierta del libro from Burgos jail (Londres, 1964).

En las páginas de la revista sueca Clarté se hablaba del éxito de la muestra londinense y se decía que era posible que la exposición de Ibarrola se pudiera ver en Estocolmo en mayo ${ }^{37}$. Finalmente la exposición de Londres no llegó a Estocolmo pero sí lo hizo una muestra de unas cincuenta obras de quince miembros de Estampa Popular entre los que se encontraban Agustín Ibarrola y María Dapena. Ésta se pudo ver entre el 31 de diciembre de 1964 y el 7 de febrero de 1965 en Gotemburgo gracias a la Sección 41 del Sindicato del Metal y al Comité por España de Gotemburgo que contaron con el Centro Español de la ciudad para seleccionar el material, además de con la colaboración de Ortega y del PCE. La muestra recorrió Suecia y llegó a Estocolmo en primavera. A juzgar por la imagen que se puede ver en el boletín ciclostilado España democrática hecho por españoles en Estocolmo, el montaje (obra de Jacob Branting) colocaba las estampas sobre paneles móviles (algunas parecen superponerse y parece adivinarse alguna obra de los artistas de Estampa Popular de Sevilla) y contaba con el golpe de efecto de un amenazante maniquí con máscara de gas en la parte superior (fig. 5). Según se indica en el boletín el día de la clausura se leyeron poemas de Carlos Álvarez traducidos al sueco y dos de las obras expuestas por Ibarrola habían sido sacadas clandestinamente de la cárcel ${ }^{38}$.

\footnotetext{
37 "Julian Grimau. Mannen - Brottet - Protesten", Clarté, 3, 1964: 21. Sobre las obras de Ibarrola en Clarté y en el LP Spanska motståndssånger de 1964 y de 1975 véase el apartado dedicado a Ibarrola en la sección "Estampa Popular" de la web donde se publica el trabajo de Cárdenas, Quintana, s/f.

38 "Arte español en Gotemburgo", España democrática, boletín ciclostilado, Estocolmo, II-1965. Enlace a documento disponible en la sección "Historia" de la web donde se publica el trabajo de Cárdenas, Quintana, s/f.
} 
Del 22 de febrero al 2 de marzo de 1964 las obras de Ibarrola se expusieron en la Galerie D'Eendt de Ámsterdam en la muestra Tentoonstelling van tekeningen in gevangenis Burgos te Spanje. La prensa holandesa informaba de que la exposición, organizada por la Conferencia de Europa Occidental en Pro de la Amnistía para los Presos y Exiliados Políticos de España, era la "protesta de un español torturado en la cárcel" 139 . REI se refería a "otro éxito de Ibarrola" difundido en emisiones de televisión y radio en español y holandés, además de en todos los periódicos. La emisora hablaba de "un público impaciente" que "esperaba su turno permaneciendo durante horas a la puerta de la galería", cifrando en más de cien mil el número de los asistentes ${ }^{40}$. Un periódico holandés hacía notar que la exposición también estaba abierta durante la noche ${ }^{41}$. Otro hablaba de dos mil quinientos visitantes en el primer fin de semana y de tal afluencia de gente, que se decidió grabar el discurso inaugural de Hans Redeker para reproducirlo en las salas. Asimismo se indicaba que habían suscitado mucho interés las fotografías de las pinturas que se vendían en la exposición para recaudar fondos para la causa ${ }^{42}$. El diplomáti-

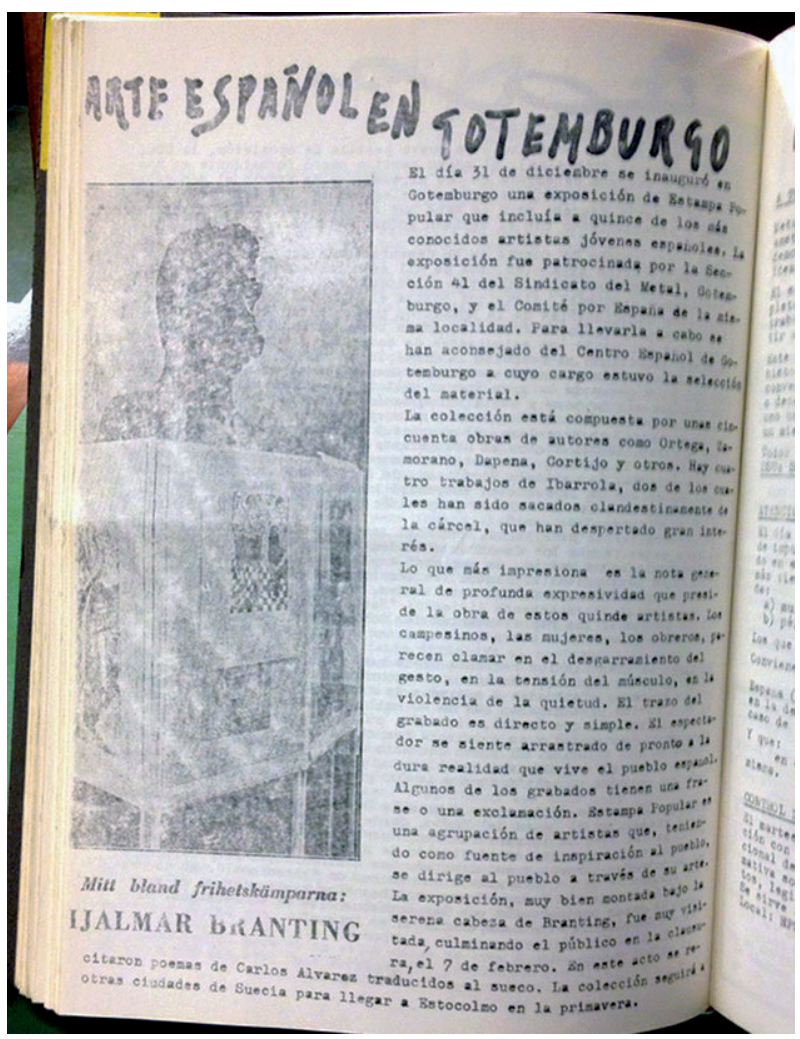

Fig. 5. Página de España democráctica sobre la exposición de Estampa Popular en Gotemburgo en 1965 (documento publicado en el trabajo de J.C. Cárdenas y E. Quintana

Ferlosio. 50 años de "Canciones de la resistencia española" - Clarté, en http://www.chichosanchezferlosio.es). co Emilio Pan de Soraluce, entonces Encargado de Negocios a.i. en La Haya, escribía que no podía "ocultar el hecho de que salvo un diario el resto de la prensa, incluidos los órganos católicos (...), ha[bía] adoptado una actitud [crítica] que (...) [coincidía] con la finalidad propuesta por los organizadores de la exposición en Holanda" cuyos folletos se distribuían en la sala y habían marcado el tono de los artículos. Relacionaba la "inusitada difusión" en prensa con

${ }^{39}$ R.E. Penning, "Dibujos de Ibarrola", Haagsche Courant, 22-II-1964. Traducción de artículo enviada con un despacho de Emilio Pan de Soraluce al Ministro de Asuntos Exteriores fechado 4-III-1964. Archivo del Ministerio de Asuntos Exteriores, Madrid (AMAE), Signatura R 7540, expediente 62.

${ }^{40}$ Otro éxito de Ibarrola. Emisión de REI de 17-III-1964 transcrita y archivada por la Oficina de Enlace. AGA, (03) 107, Caja 42/8801, dossier de Agustín Ibarrola Goicoechea.

${ }_{41}$ R.E. Penning, "Dibujos de Ibarrola", Haagsche Courant, 22-II-1964. Traducción de artículo enviada con un despacho de Emilio Pan de Soraluce al Ministro de Asuntos Exteriores fechado 4-III-1964. AMAE, Signatura R 7540, expediente 62 .

42 "Interés abrumador por dibujos de Ibarrola", Algemeen Handelsblad, 24-II-1964. Traducción de artículo enviada con un despacho de Emilio Pan de Soraluce al Ministro de Asuntos Exteriores fechado 4-III-1964. AMAE, Signatura R 7540 , expediente 62 . 


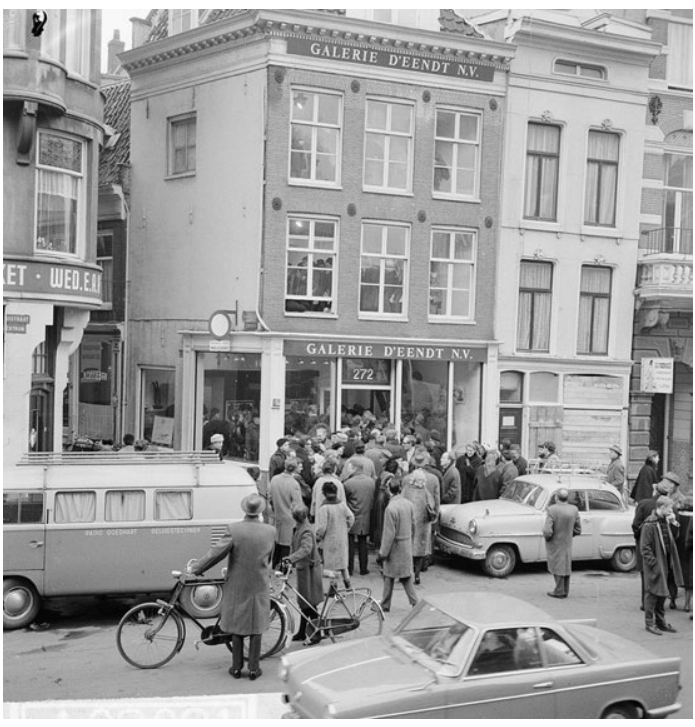

Fig. 6. Exterior de la Galerie D’Eendt de Amsterdam. Inauguración de la exposición Tentoonstelling van tekeningen in gevangenis Burgos te Spanje en 1964 (NL-HaNA, ANEFO).

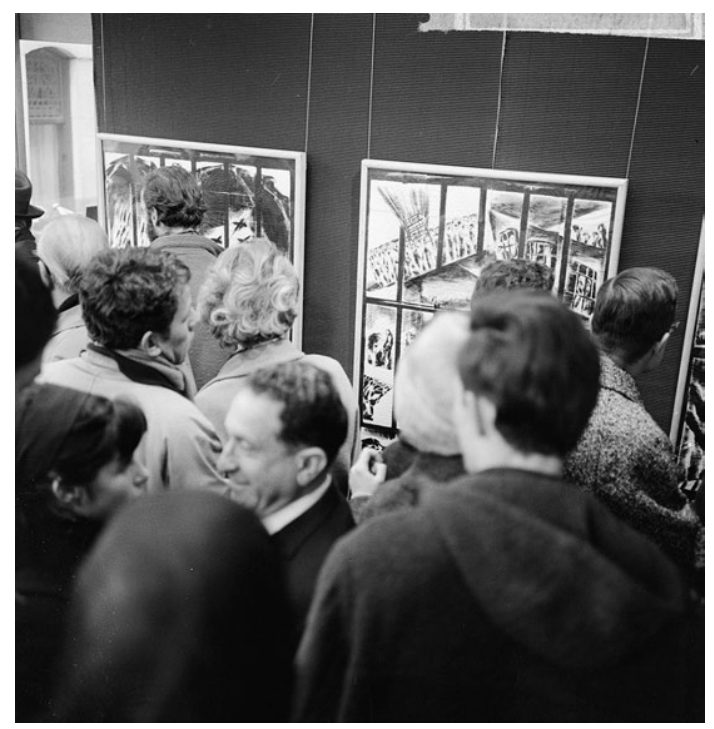

Fig. 7. Paneles de Ibarrola Ayer y Hoy expuestos en la Galerie D'Eendt de Amsterdam. Inauguración de la exposición Tentoonstelling van tekeningen in gevangenis Burgos te Spanje en 1964 (NL-HaNA, ANEFO).

el hecho de que aún estuviera candente "el asunto de la Princesa Irene" ${ }^{\text {"43 }}$. En efecto la conversión al catolicismo de la princesa holandesa y los rumores sobre su posible matrimonio con CarlosHugo de Borbón-Parma (hijo mayor del pretendiente carlista al trono de España) habían suscitado protestas y críticas al régimen franquista que seguramente encontraban en las obras de Ibarrola un argumento más.

Ciertamente las fotografías de la inauguración muestran una galería abarrotada ${ }^{44}$ (fig. 6). A su puerta se agolpan las personas y se asoman los curiosos. Los grupos que se saludan y conversan animadamente en la calle no parecen estar simplemente esperando su turno para entrar. Como toda inauguración, parece ser también un acto social adonde se acude para encontrarse con amigos y colegas. Seguramente esta muestra fue un punto de encuentro para el público habitual de las galerías pero también para los simpatizantes del movimiento antifranquista y de la defensa de los derechos humanos. Se había reservado un lugar destacado de la sala para los tres paneles de mayor tamaño. Éstos recibían al visitante que entraba enmarcados con delgados marcos claros que destacaban sus dimensiones en la pared oscura de la que colgaban (fig. 7). Las obras más pequeñas, por su parte, estaban protegidas por un simple cristal y, como se ve en las fotografías, su disposición quería invitar a la observación detallada. Entre ellas se encontraban, por ejemplo, las imágenes de la ventana de la celda del artista o la de un preso en una celda de castigo (fig. 8). Esta obra, titulada 5 años incomunicado, sería reproducida en varios de los carteles diseñados en los años setenta por la artista Iris de Leeuw para la organización holandesa

${ }^{43}$ Despacho enviado por Emilio Pan de Soraluce al Ministro de Asuntos Exteriores fechado 4-III-1964. AMAE, Signatura R 7540, expediente 62 .

${ }^{44}$ Nationaal Archief, Den Haag, Rijksfotoarchief (NL-HaNA). Collectie Algemeen Nederlands Fotopersbureau (ANEFO). Toegangen 2.24.01.03. Num. 916-0796 a 916-0801. 


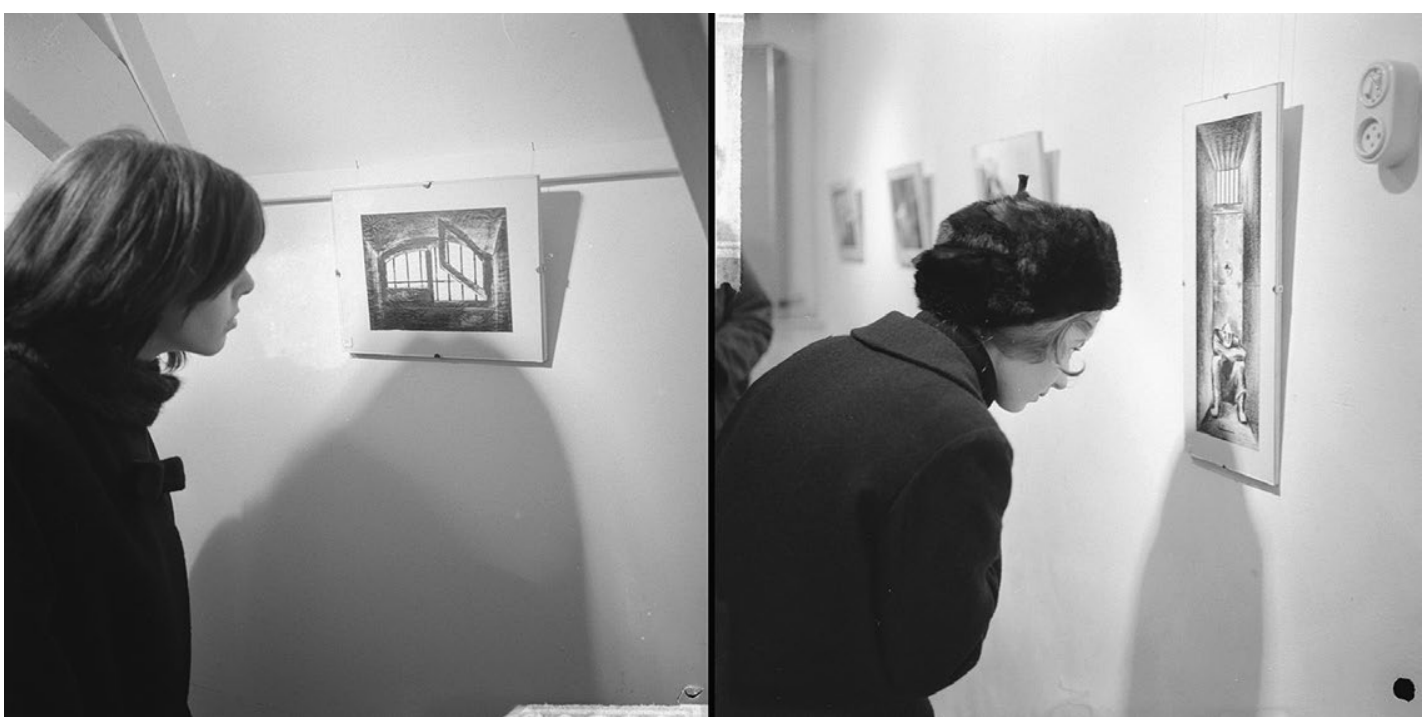

Fig. 8. Obras de Ibarrola La ventana y 5 años incomunicado expuestas en la Galerie D'Eendt de Amsterdam. Inauguración de la exposición Tentoonstelling van tekeningen in gevangenis Burgos te Spanje en 1964

(NL-HaNA, ANEFO).

Acción Fuego ${ }^{45}$. En uno de los escaparates de la galería, orientado hacia una pequeña calle lateral, se exponía la litografía de Picasso titulada Colombe de l'avenir que fue editada en esos años y que había sido la imagen del Congrès Mondial pour le Désarmement Général et la Paix celebrado en Moscú en julio de 1962. También aquí la figura de Picasso complementaba y reforzaba el mensaje de la exposición de Ibarrola.

Algunas de las obras expuestas en Holanda, junto con poemas de Marcos Ana y Vidal de Nicolás, fueron publicados en un nuevo libro $^{46}$. La introducción, firmada por Hans Redeker, era seguramente un texto similar o idéntico al leído en la inauguración. Aquí había 13 poemas de Marcos Ana y 5 de Vidal de Nicolás, y se reproducían 22 pinturas de Ibarrola. Ilustraban la cubierta (en un dramático contraste de negro y rojo vivo) las siluetas de dos guardias civiles, uno de ellos empuñando su arma con la bayoneta calada (fig. 9). En ésta como en otras obras llaman la atención las arrugas del soporte. Su presencia hacía pensar, como indicaba la prensa, que había sido imposible eliminarlas ${ }^{47}$. Se debían seguramente a los medios empleados para hacer salir las obras de la cárcel, quizá también a la técnica pictórica. En todo caso, sus causas tenían que ver con las precarias condiciones de realización y difusión de las obras: en cierto sentido, eran marcas

${ }^{45}$ Acción Fuego fue fundada por Rients Dijkstra, minusválido a causa de haber combatido en las Brigadas Internacionales en la Guerra Civil. De vuelta en Holanda, dedicó su tiempo y sus esfuerzos a continuar la lucha, llevando a cabo iniciativas para recaudar fondos y ayudar a los exiliados, a los presos políticos y a sus familias. Él mostró a Iris esta obra de Ibarrola para que la utilizara en el póster de Accion Fuego. Testimonio de Iris de Leeuw en comunicación electrónica con la autora 28-VIII-2012.

${ }^{46}$ VV.AA. Agostin Ibarrola. Tekeningen uit de gevangenis van Burgos met gedichten van Marcos Ana en Vidal de Nicolas, Amsterdam, Van Ditmar, s/f [1965].

${ }^{47}$ Nico Verhoeven, "Dibujos de un preso político español", De Tijd - De Maasbode, 27-II-1964. Traducción de artículo enviada con un despacho de Emilio Pan de Soraluce al Ministro de Asuntos Exteriores fechado 4-III-1964. AMAE, Signatura R 7540, expediente 62. 


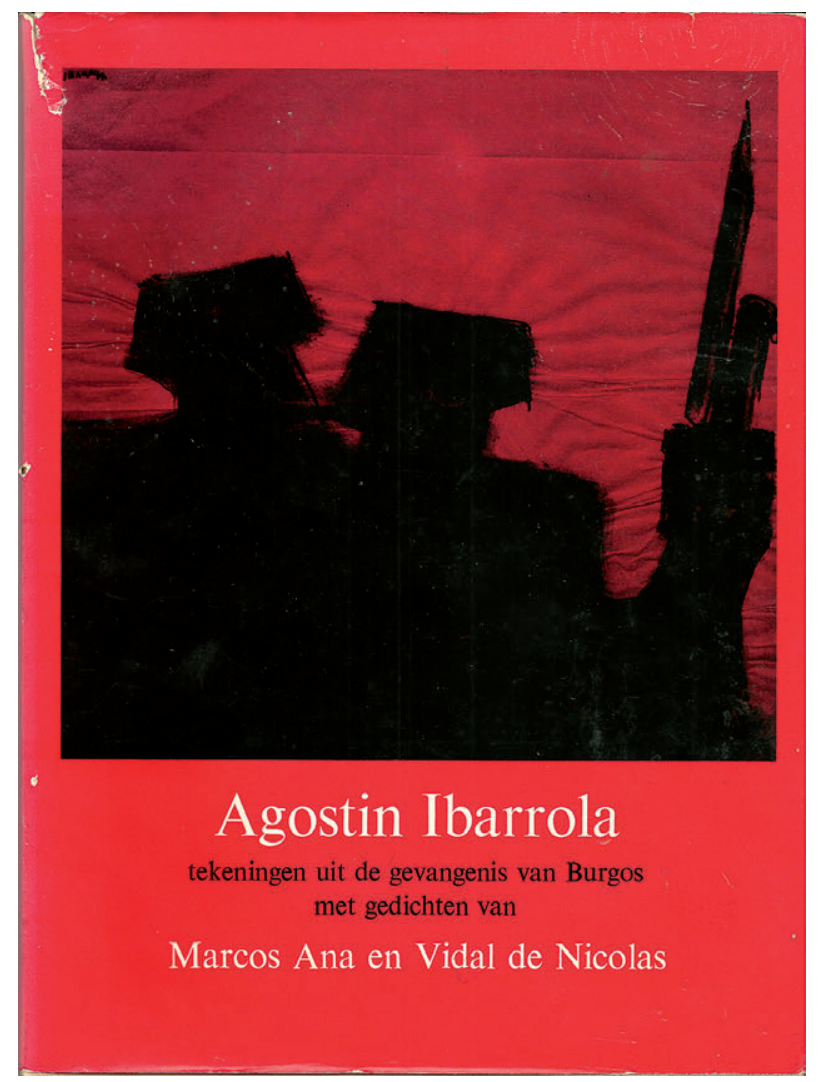

Fig. 9. Obra de Ibarrola reproducida en la cubierta del libro Agostin Ibarrola. Tekeningen uit de gevangenis van Burgos met gedichten van Marcos Ana en Vidal de Nicolas (Ámsterdam, 1965).

de la dureza del régimen retratado. REI difundió algunas anécdotas sobre la recepción de la exposición en Ámsterdam como, por ejemplo, que un día había aparecido un ramo de tulipanes rojos ante un fusilamiento que se hacía eco de la obra de Goya, que la exposición había sido interpretada por un periódico como un homenaje "a las víctimas del franquismo, desde Federico García Lorca hasta Julián Grimau" o que un diputado católico había tenido que explicar a su hijo cada dibujo porque éste "no comprendía esos horrores en el siglo XX",

Según REI, a causa de estas exposiciones, Ibarrola no había sido rehabilitado como los demás presos que habían escrito a Fraga solidarizándose con los 102 intelectuales que le habían pedido cuentas por los malos tratos sufridos por los mineros asturianos en huelga y sus mujeres $^{49}$. Por ello REI lanzaba un llamamiento a pintores, artistas y escritores para exigir a la Dirección General de Prisiones que el pintor fuera rehabilita$\mathrm{do}^{50}$. Menos de un mes más tarde se enviaba una carta abierta al Ministro de Justicia firmada por personalidades del mundo del arte (que se presentaban como miembros del movimiento internacional de la Nouvelle Tendance) pidiendo el respeto a las libertades fundamentales en España así como la libertad de Ibarrola cuyo encarcelamiento le impedía participar en las actividades de este movimiento artístico ${ }^{51}$. Según contaba REI semanas después, el encierro en la celda de castigo se debía a que Ibarrola había protestado ante el director de la prisión porque el funcionario que les vigilaba le había prohibido hablar con su mujer del éxito de una de sus ex-

${ }^{48}$ Otro éxito de Ibarrola. Emisión de REI de 17-III-1964 transcrita y archivada por la Oficina de Enlace. AGA, (03) 107, Caja 42/8801, dossier de Agustín Ibarrola Goicoechea.

${ }_{49}$ Las cartas, las respuestas de Fraga así como las cartas de varios mineros asturianos y las de un grupo de presos de Burgos (en la que se hacía referencia a las torturas sufridas, entre otros, por Ibarrola) se habían publicado bajo el título "Los intelectuales contra la tortura y por las libertades democráticas", Realidad, 2, XI-XII-1963: 122-139.

${ }^{50}$ Medidas discriminatorias contra Agustín Ibarrola en el Penal de Burgos. Emisión de REI de 21-III-1964 transcrita y archivada por la Oficina de Enlace. AGA, (03) 107, Caja 42/8801, dossier de Agustín Ibarrola Goicoechea.

${ }^{51}$ Lettre ouverte à Monsieur le Ministre de la Justice, París, 17-IV-1964. Copia archivada por la Oficina de Enlace. AGA, (03) 107, Caja 42/8801, dossier de Agustín Ibarrola Goicoechea. 
posiciones. Según REI la protesta de los presos de Burgos había conseguido que el director de la cárcel les asegurase que se iba a resolver el castigo a Ibarrola ${ }^{52}$.

Después de Ámsterdam las pinturas de Ibarrola viajaron a Italia. El grupo de trabajo "Problemi della pace" del Comitato Regionale Emiliano del Partito Comunista Italiano (PCI) propuso organizar en Bologna una manifestación de ámbito nacional de solidaridad del antifascismo italiano con la lucha española. El evento coincidía con el aniversario del asesinato de Grimau y formaba parte de las celebraciones del vigésimo aniversario de la resistencia al fascismo, así como de las iniciativas que buscaban desenmascarar a la dictadura franquista, que celebraba sus veinticinco años "de paz" en $1964^{53}$. El programa del evento se iniciaba con la inauguración el día 18 de abril de la exposición de Ibarrola en la Galleria del Sottopassaggio (la muestra estaría abierta hasta el 3 de mayo). Después tendría lugar una manifestación en la que intervendrían personalidades del antifascismo español e italiano junto con Ángela Grimau. Finalmente, el 20 de abril tendría lugar una reunión de los Garibaldini di Spagna. Se pretendía que esta manifestación fuera la más importante de todas las que se hicieran en Europa contra la "paz" franquista y que fuera una especie de equivalente al homenaje a Machado que iba a reunir a muchos intelectuales europeos en París ${ }^{54}$. El catálogo de la exposición incluía escritos de Roberto Matta, José Ortega y Franco Solmi, la reproducción de parte del interrogatorio a Ibarrola publicado en Rinascita, la versión italiana del llamamiento a los intelectuales para que se levantaran las sanciones impuestas a Ibarrola y pinturas de este último ${ }^{55}$. A finales de ese año, la Sezione per l'Estero del PCI publicaba Spagna in prigione, un librito sobre la situación de los presos políticos en España, sus demandas y los movimientos de protesta que les apoyaban, donde también había reproducciones de obras de Ibarrola ${ }^{56}$. En el marco estas manifestaciones culturales y políticas italianas, la exposición España libre itineraba desde el verano de 1964 por varias ciudades ${ }^{57}$. En ella se dedicaba una sección específica a Ibarrola, también presente en el apartado dedicado a Estampa Popular. De entre las obras de Ibarrola reproducidas en el catálogo, el aspecto de la titulada Figuras hace pensar que pudiera tratarse de una de las pinturas de la cárcel. Las contribuciones al catálogo de los críticos de arte Vicente Aguilera Cerni y José María Moreno Galván estaban dedicadas precisamente a Ibarrola y al crítico de arte Giménez Pericás ${ }^{58}$. Ese mismo año, con el apoyo expreso de Vicente Aguilera Cerni, la Asociación Internacional de la Crítica de Arte (AICA), incorporó a Giménez Pericás entre sus miembros. La AICA firmó también en esa reunión, que coincidía con la Bienal de Venecia, una carta en solidaridad con los encarcelados por motivos ideológicos ${ }^{59}$. Esto era anunciado por REI

${ }^{52}$ La emisión de REI indica que Agustín Ibarrola y Mariluz Bellido hablaban de una exposición en París de la que no tenemos noticia (a no ser que se tratara de alguna de las muestras colectivas). Es posible que se refirieran a alguna de las exposiciones que se celebraron en otras ciudades. Humillación y castigos en la prisión de Burgos. Emisión de REI de 10-VI-1964 transcrita y archivada por la Oficina de Enlace. AGA, (03) 107, Caja 42/8801, dossier de Agustín Ibarrola Goicoechea.

${ }^{53}$ De Haro, 2010b: 367-378.

${ }^{54}$ Nota enviada al Ufficio di Segreteria por Renato Sandri, fechada en Roma, 26-III-1964. Fondazione Istituto Gramsci, Roma (FIG), 0520 2193-0520 2195.

${ }_{55}$ VV.AA. Bologna antifascista per Agustín Ibarrola (folleto exposición), Bologna, Galleria del Sottopassaggio, 1964.

56 VV.AA. Spagna in prigione, Roma, Sezione per l'Estero del PCI, 1964. FIG, 0520 2257-0520 2295.

${ }^{57}$ Sobre la exposición véanse Núñez, 2004: 737-754 y Núñez, 2002.

${ }^{58}$ Vicente Aguilera, "Sul significato di una cultura libera" y José María Moreno, "Significación de una cultura libre", en España libre (catálogo exposición), Rímini, Grafiche Gattei, 1964, s/p.

${ }_{59}$ No se trataba de un apoyo aislado por parte de la AICA. Ya en 1962 la crítica de arte exiliada Margaria Nelken había pedido en la asamblea de la AICA celebrada en México DF que se apoyara a los artistas que acababan de ser detenidos en España durante las huelgas, sometidos a un "juicio militar injusto" y que se pidiera para ellos un juicio civil. Sobre el apoyo de la AICA a los presos de Burgos véase Barreiro, 2014: 137-138. Acerca de la carta de 1964 véase también Núñez, 2002: 40. 
que se refería a cómo ciento doce pintores y críticos de arte habían firmado una carta donde se pedía al gobierno franquista la libertad de Ibarrola y Giménez Pericás ${ }^{60}$. Mientras tanto, en Reino Unido, el artista argentino Leopoldo Maler filmaba Men in silence, un film en el que la cámara recorría las pinturas de Ibarrola guiada por los versos de Marcos Ana. La película fue elegida como el corto más sobresaliente de 1964 en el Festival Cinematográfico de Londres ${ }^{61}$ y ese mismo año ganó un premio especial en el 7. Leipziger Dokumentär und Kurzfilmwoche ${ }^{62}$. Hay noticias de que la película fue ofrecida a varias organizaciones italianas para ser proyectada aunque no sabemos a ciencia cierta si las gestiones tuvieron éxito ${ }^{63}$. Algunas de las obras hechas por Ibarrola en la cárcel se publicaron (bajo el título Carnets de prison) en el número especial de Démocratie nouvelle dedicado a España ${ }^{64}$. Una nota de la Oficina de Enlace en la que se daba cuenta de los autores de textos e imágenes señalaba que esta publicación era "un medio más dirigido a realizar contrapropaganda de la campaña española de los XXV Años de Paz"65.

Mariluz Bellido organizó varias exposiciones de su marido en España. La primera se celebró, del 29 de agosto al 10 de septiembre de 1964, en la Sala Capitel de Santander gracias a la mediación de un amigo. Seguramente se trataba de Miguel Vázquez que, según la Oficina de Enlace, había presentado la iniciativa a Enrique Pereda Barros ("conocido por su tradicionalismo y adhesión al régimen") para que hiciera la propuesta al "conocido tradicionalista" Manuel Pereda de la Reguera, dueño de la sala y autor de la presentación de la muestra. Al parecer se había decidido no prohibir la exposición para no llamar la atención, puesto que Ibarrola era "desconocido en la ciudad". Es de suponer que esta estrategia tuvo éxito puesto que tanto la Oficina de Enlace ${ }^{66}$ como Mariluz afirman que la exposición no tuvo apenas repercusión. Entre el 11 y el 20 de diciembre se abrió una nueva muestra en la sala Cristamol de Oviedo. Mariluz Bellido cuenta que esta exposición se realizó "sin ayuda de amigos", gracias a que el dueño de la sala se enteró de su situación y le ofreció organizar la muestra. Allí se llevó la obra "más virulenta" de Ibarrola, en su mayoría cuadros y murales hechos antes de la detención aunque también hubo "alguna obra de la cárcel". En este caso las dos radios locales y los periódicos se hicieron eco de la muestra ${ }^{67}$. La Oficina de Enlace, atenta sólo a posibles consecuencias políticas, anotaba que la exposición "no tuvo repercusión alguna ni en la opinión pública ni en los medios políticos, y transcurrió como una exposición más de las que se celebran en aquella sala, sin trascendencia especial alguna" ${ }^{" 68}$.

En cambio, el 30 de diciembre de ese mismo año la exposición de Ibarrola que tenía que haberse inaugurado en la Sala Illescas de Bilbao fue prohibida a pesar de la autorización inicial. Ibarrola envió una carta de protesta a Fraga puesto que esto impedía que su familia pudiera sustentarse con la exposición y venta de sus pinturas ${ }^{69}$. Es evidente que el régimen calibraba su nivel

\footnotetext{
${ }^{60}$ Petición de libertad de Ibarrola y Antonio García [sic] Emisión de REI de 17-VII-1964, transcrita y archivada por la Oficina de Enlace. AGA, (03) 107, Caja 42/8801, dossier de Agustín Ibarrola Goicoechea.

${ }^{61}$ Testimonio de Leopoldo Maler en comunicación electrónica con la autora, 21-XII-2012.

62 "Festlicher Abschluß", Neues Deutschland, 22-XI-1964: 1.

63 "Una voz desde las cárceles de Franco", Il giorno, 22-XI-1964. Recorte de prensa archivado por la Oficina de Enlace. AGA, (03) 107, Caja 42/8801, dossier de Agustín Ibarrola Goicoechea.

${ }^{64}$ Démocratie nouvelle, número especial, XII-1964.

65 "Democratie nouvelle", nota de la Oficina de Enlace de fecha 19-I-1965. AGA, (03) 107, Caja 42/8801, dossier de Agustín Ibarrola Goicoechea.

${ }^{66}$ Exposición de Agustín Ibarrola en Santander. Nota de la Oficina de Enlace fechada 29-I-1965. AGA, (03) 107, Caja 42/8801, dossier de Agustín Ibarrola Goicoechea.

${ }^{67}$ Angulo, 1978: 164

${ }^{68}$ Exposición de Ibarrola en Oviedo. Nota de la Oficina de Enlace fechada 29-I-1965. AGA, (03) 107, Caja 42/8801, dossier de Agustín Ibarrola Goicoechea.

${ }^{69}$ Carta de Agustín Ibarrola al Ministro de Información y Turismo Manuel Fraga, fechada en la Prisión Central de Burgos, 9-I-1965. AGA, (03) 107, Caja 42/8801, dossier de Agustín Ibarrola Goicoechea.
} 
de permisividad en función de las características de cada caso concreto. No gustaba el tratamiento de los temas en los cuarenta cuadros de Illescas pero, sobre todo, no se quería correr el riesgo de que la muestra se convirtiera en detonante y catalizador de manifestaciones políticas. El Gobernador Civil de Vizcaya explicaba al Delegado Provincial del MIT que se había tomado esta decisión a causa de "los antecedentes políticos del pintor y el carácter de sus cuadros". Éstos representaban "temas de carácter social y laboral dentro de la rama metalúrgica y de marinos (...) tratados con dureza", de entre ellos destacaba uno que mostraba a "un individuo recluido en una especie de celda en actitud angustiosa" (¿quizá la obra 5 años incomunicado?). Puesto "que fue en Bilbao donde se desarticuló la organización comunista a la que pertenecía" se temía que "pudiera dar lugar esta exposición a cualquier forma o manera de exteriorizar por parte de algún sector visitante una adhesión o simpatía hacia el Sr. Ibarrola no como pintor sino en su aspecto político"70. Con todo, los comunistas españoles vieron las obras de Ibarrola bajo un explícito prisma político cuando algunas fueron reproducidas en Nuestra Bandera. El número de enero de 1965 de esta publicación del PCE, dedicado enteramente a discutir el "Documento plataforma fraccional de Fernando Claudín", estrenaba nueva etapa y reproducía cuatro de las pinturas realizadas en el penal de Burgos ${ }^{71}$.

Fuera de las fronteras españolas, hasta el 6 de febrero de 1965 se pudieron ver obras de Ibarrola como la seda Los esclavos de los 25 años franquistas, en la muestra colectiva Artistes espagnols celebrada en la Maison du Parti Communiste Français de Rouen y organizada por la Union d'Artistes Peintres de esta localidad ${ }^{72}$. Mientras tanto AAS y el Comité Français pour l'Espagne habían llegado a un acuerdo para celebrar en Londres la Conferencia de Europa Occidental contra la Represión en España en marzo de 1965. Quizá el acuerdo entre ambas organizaciones facilitó que durante el mes de junio de ese año se expusieran en París las obras de Ibarrola. La muestra se inauguró el 9 de junio en la galería Epona ${ }^{73}$, que ya había organizado otras exposiciones de antifranquistas españoles ${ }^{74}$. Mariluz Bellido, que estuvo allí, recuerda con emoción que, gracias a ella Jean Cassou escribió la presentación del catálogo, y que Rafael Alberti leyó un texto en la inauguración ${ }^{75}$ en el que deseaba la libertad de todos los que penaban, como Ibarrola, en las cárceles españolas ${ }^{76}$. A la muestra no sólo habían acudido personalidades del mundo intelectual y político: junto con Mariluz había estado allí Ángela Grimau ${ }^{77}$. Las imágenes muestran no sólo que habían continuado saliendo clandestinamente más pinturas de Ibarrola de la cárcel de Burgos (en la exposición parisina había un total de 52 obras $^{78}$ ), sino que, efectivamente, muchas eran de gran tamaño (fig. 10). La sorpresa que experimentaba el público estaba motivada, pues, tanto por los temas tratados como por las dificultades que entrañaba pintar y hacer salir de forma clandestina

${ }^{70}$ Oficio del Gobernador Civil de Vizcaya al Delegado Provincial del MIT, fechado en Bilbao, 29-XII-1964. AGA, (03) 107, Caja 42/8801, dossier de Agustín Ibarrola Goicoechea.

${ }^{71}$ Nuestra Bandera, $\mathrm{n}^{\circ} 40$, enero de 1965.

${ }^{72}$ Artistes Espagnols, (folleto exposición), Rouen, Maison du PCF, II-1965. Archivo personal de Gérard y Georgette Gosselin (AGGG)

${ }^{73}$ La fecha de la inauguración es la proporcionada en la agencia de prensa checoslovaca eská tisková kancelá (CTK), Exposición Ibarrola inaugurada en París. Noticia traducida y archivada por la Oficina de Enlace. AGA, (03) 107, Caja 42/8801, dossier de Agustín Ibarrola Goicoechea.

${ }^{74}$ Sobre este tema véase De Haro, 2010a.

7 Testimonio de Mariluz Bellido, en conversación con Agustín Ibarrola, José Ibarrola, José Ángel Etxániz y la autora, Kortezubi (Vizcaya), 12-III-2011.

${ }^{76}$ Texto de Rafael Alberti leído en la inauguración de la exposición de Agustín Ibarrola en la galería Epona de París. Archivo personal de Mariluz Bellido y Agustín Ibarrola.

77 "L'exposition du peintre espagnol Ibarrola (détenu à Burgos) a été inaugurée hier", L'Humanité, 9-VI-1965. AGGG.

${ }^{78}$ Jean Rollin, “L’enfermé de Burgos”, L'Humanité, VI-1965. AGGG. 


\section{L'exposition du peintre espagno IRARDI. (détenu à Burgos) a été inaugurée hier}

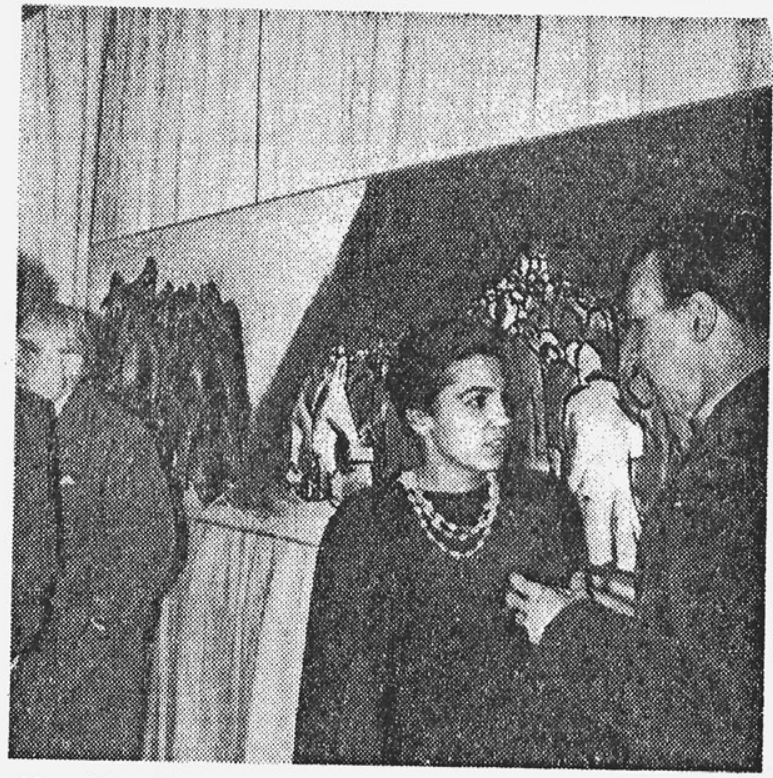

Mme Ybarrola en conversation avec V. Pozner. On reconnait, à gauche, Rafaël Alberti

Fig. 10. Mariluz Bellido, V. Pozner y Rafael Alberti ante uno de las obras de gran tamaño de Ibarrola expuestas en la galería Epona de París en 1965 (extraída de L’Humanité).

unas obras que parecían murales. Junto con ello, el comentario acerca de los tonos ocres y sepia empleados hace pensar que dicha elección cromática resultaba llamativa ${ }^{79}$. Quizá estos colores hacían pensar en las telas como un lugar en el que se conservaba la huella de la tortura al margen del tema representado. No es descabellado pensar en las sedas como paños o sudarios manchados por el contacto con la carne de los cuerpos maltratados.

REI anunciaba en julio de 1965 que las obras de Ibarrola se podían ver en Toulouse si bien no sabemos dónde ni cuándo tuvo lugar la exposición ${ }^{80}$. En octubre de 1965 se entregaba en la Embajada de España de Río de Janeiro un documento firmado por intelectuales brasileños interesándose por la puesta en libertad de Ibarrola y Giménez Pericás. Una copia de este documento, redactado con motivo de la VII Bienal de Sâo Paulo, se entregó a Mario Pedrosa y Giulio Carlo Argan, presidente de la $\mathrm{AICA}^{81}$. Una nueva exposición de Ibarrola tuvo lugar en las salas del Volksbildungsheim de Frankfurt del 10 septiembre al 10 octubre de 1965. La muestra había sido organizada por el Círculo Cultural de Frankfurt, existiendo la posibilidad de que viajara a otras ciudades alemanas $^{82}$. Ese año, en Múnich, el historiador del arte Richard Hiepe se encargaba del número especial que la revista tendenzen dedicaba al arte en España. En la cubierta la imagen de la ventana de la celda de Ibarrola daba la bienvenida a los lectores, en sus páginas se incluían, entre otros, artículos sobre la situación del pintor y sus exposiciones y reproducciones de algunas de sus obras $^{83}$. Por otro lado, ese año se publicaba Burgos, prisión central donde los textos de Giménez Pericás y las imágenes de Ibarrola mostraban la vida en esta prisión franquista. Estas imágenes

${ }^{79}$ Exposición de pinturas de IBARROLA en París. Documento remitido por el Alto Estado Mayor a la Oficina de Enlace, 30-VI-1965, AGA, (03) 107, Caja 42/8801, dossier de Agustín Ibarrola Goicoechea.

80 "Exposición de Ibarrola en Toulouse". Emisión de REI de 28-VII-1965 transcrita y archivada por la Oficina de Enlace. AGA, (03) 107, Caja 42/8801, dossier de Agustín Ibarrola Goicoechea.

81 "Un grupo de intelectuales pide la liberación de un crítico español", Corriere da Manha, 1-X-1965. Traducción de artículo enviado a la Oficina de Enlace por los Servicios Informativos de la Dirección General de Prensa. AGA, (03) 107, Caja 42/8801, dossier de Agustín Ibarrola Goicoechea.

82 "Exposición de las obras de Ibarrola en Alemania". Nota del Alto Estado Mayor a la Oficina del Enlace fechada 24-V-1965. AGA, (03) 107, Caja 42/8801, dossier de Agustín Ibarrola Goicoechea.

${ }^{83}$ Tendenzen, número especial, 1965. 


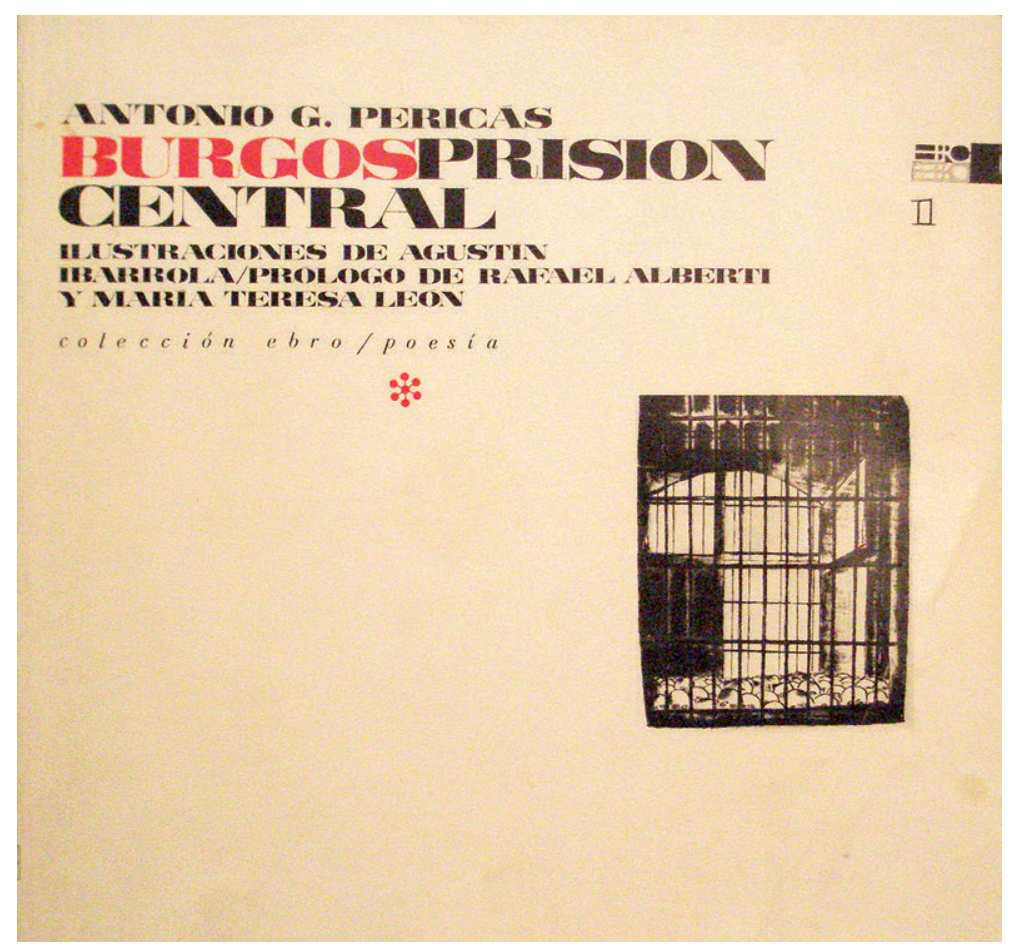

Fig. 11. Cubierta del libro Burgos, Prisión Central (París, 1965).

eran "los desastres de la paz" (fig. 11). Para María Teresa León y Rafael Alberti, que firmaban el prólogo al libro, en sus páginas se hablaba y se representaba a todos los hombres del penal de Bur$\operatorname{gos}^{84}$. No en vano, el libro estaba dedicado a quienes habían sido fusilados en el patio de las acacias en esa misma prisión, durante la guerra.

El 23 de septiembre de 1965 Agustín Ibarrola salía de la Prisión Central de Burgos en libertad condicional. Un mes más tarde REI anunciaba que más de cien personas habían recibido al pintor en la estación de Bilba ${ }^{85}$. Seguirían las exposiciones, también las manifestaciones, más detenciones y años de cárcel. Habría nuevas exposiciones de denuncia gracias a las redes de solidaridad y apoyo a los presos políticos, las demandas de amnistía, el movimiento antifranquista y las organizaciones de defensa de los derechos humanos.

Gracias a estas pinturas de Ibarrola, hoy en paradero desconocido, y a su circulación, podemos hacernos una idea de la extensión y funcionamiento de las redes de apoyo al antifranquismo. Gervasio Puerta se refiere a toda una estructura de colaboradores que posibilitaba la circulación de mensajes en la prisión. La formaban presos, personas en los servicios de paquetes y hasta tres funcionarios de prisiones. También se contaba con personas fuera de la cárcel, de entre ellas Puerta elogia y agradece especialmente la labor llevada a cabo por compañeras y madres de $\operatorname{presos}^{86}$. Todo ello constituía un tejido de hebras finas, en ocasiones casi invisibles, pero muy resistentes. Tanto

${ }^{84}$ María Teresa León, Rafael Alberti, "Burgos, prisión central”, en VV.AA., Burgos, prisión central, París, Éditions de la Librairie du Globe, 1965: 9-11.

85 "Actualidades españolas". Emisión de REI de 23-X-1965, transcrita y archivada por la Oficina de Enlace. AGA, (03) 107, Caja 42/8801, dossier de Agustín Ibarrola Goicoechea.

${ }^{86}$ Puerta, 2011: 107-116. 
como los hilos de seda. Éstos unían las celdas de castigo franquistas no sólo con el mundo exterior, sino también con otros países: de Reino Unido a Alemania, de Suecia a Italia. Gracias a esta red de apoyo y reivindicación política las voces de los presos y sus allegados se hicieron audibles más allá de los muros de sus celdas. Sus mensajes, entre los que se cuentan los versos de Marcos Ana, Vidal de Nicolás o Giménez Pericás, así como las sedas pintadas por Ibarrola, fueron un elemento fundamental en las campañas de solidaridad y apoyo internacionales a favor de la amnistía y la defensa de los derechos humanos.

\section{BIBLIOGRAFÍA}

Angulo, Javier (1978): Ibarrola ¿un pintor maldito?, San Sebastián, Haranburu.

Cárdenas, José Cristóbal / Quintana, Emilio (1964): Ferlosio. 50 años de “Canciones de la resistencia española" - Clarté, s/f. Disponible en línea $<$ http://www.chichosanchezferlosio.es> [14-IX-2014].

Barreiro, Paula (2009): La abstracción geométrica en España, Madrid, CSIC, 2009.

Barreiro, Paula (2014): "Redes críticas: encuentros e intercambios de España a la Europa de la Guerra Fría". En: Cabañas Bravo, Miguel, Rincón García, Wifredo (eds.), Las redes hispanas del arte desde 1900, Madrid, CSIC, pp. 129-142.

Buchanan, Tom (2002): "The truth will set you free: the making of Amnesty International". En: Journal of Contemporary History, 37: 4, p. 575-597.

Dapena, María Francisca (1978): ;Sr. Juez! (soy presa de Franco... ), San Sebastián, Haranburu.

De Haro, Noemi (2010a): Grabadores contra el franquismo, Madrid, CSIC.

De Haro, Noemi (2010b): “Contra XXV Años de Paz". En: Cabañas, Miguel / López-Yarto, Amelia / Rincón, Wifredo: Arte en tiempos de guerra, Madrid, CSIC, pp. 367-378.

De Haro, Noemi (2014): "El papel de las imágenes en Appeal for Amnesty in Spain”. En: Cabañas Bravo, Miguel / Rincón García, Wifredo (eds.): Las redes hispanas del arte desde 1900, Madrid, CSIC, pp. 107-120.

Núñez, Mónica (2002): “XXV Años de Paz-Ventennale Della Resistenza: rentabilidad y descrédito de la política artística española en Italia”, trabajo de investigación inédito dirigido por Mª Dolores Jiménez Blanco y Miguel Cabañas, Universidad Complutense de Madrid.

Núñez, Mónica (2004): "Los caminos del arte español en Italia: una evocación de la resistencia”. En: Congreso de Caminería Hispánica, Madrid, Ministerio de Fomento, 2004, pp. 737-754.

Puerta, Gervasio (2011): Palomas tras las rejas. Recuerdos de un luchador antifranquista, presidente de la Asociación de Expresos, Madrid, Endymion.

Wye, Deborah (2006): Eye on Europe: Prints, Books \& Multiples, 1960 to Now, Nueva York, Museum of Modern Art.

Fecha de recepción: 16-IX-2014

Fecha de aceptación: 15-XII-2014 